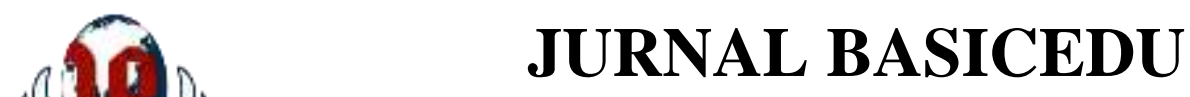

Volume 5 Nomor 5 Tahun 2021 Halaman 3460 - 3471

Research \& Learning in Elementary Education https://jbasic.org/index.php/basicedu

\title{
Pengembangan Pembelajaran Blended Learning Berbasis Model Flipped Learning untuk Meningkatkan 6C For HOTS Mahasiswa PGSD UMSU
}

\author{
Suci Perwita Sari ${ }^{1 凶}$, Eko Febri Syahputra Siregar², Baihaqi Siddik Lubis ${ }^{3}$ \\ Universitas Muhammadiyah Sumatera Utara, Indonesia ${ }^{1,2,3}$ \\ E-mail: $\underline{\text { suciperwita@umsu.ac.id }}{ }^{1}, \underline{\text { ekofebrisyahputra@umsu.ac.id }}^{2}, \underline{\text { baihaqisiddik@umsu.ac.id }}^{3}$
}

\begin{abstract}
Abstrak
Penelitian pengembangan ini bertujuan untuk meningkatkan 6C for HOTS mahasiswa melalui pengembangan model Blended Learning berbasis Flipped Learning. Adapun 6C yang dimaksud adalah critical thinking, creative skill, communication skill, collaborative skill, computation skill dan compassion. Untuk proporsi model Blended Learning berbasis Flipped Learning dilakukan sebesar 10\% tatap muka dan 90\% melalui daring. Metode dalam penelitian menggunakan metode ADDIE. Langkah langkah ADDIE adalah analisis (analyze), perancangan (design), pengembangan (development), implementasi (implementation), dan evaluasi (evaluation). Berdasarkan hasil perhitungan dan pembahasan dapat disimpulkan bahwa model pembelajaran Blended Learning berbasis Flipped Learning sangat efektif dalam meningkatkan 6C for HOTS mahasiswa. Hal ini dapat dilihat dari hasil pehitungan keterampilan berpikir kritis (critical thinking) mahasiswa dari rerata 36,67 menjadi 88,28. Pada keterampilan berpikir kreatif (creative skill) terjadi peningkatan dari rerata 60,77 mrnjadi 87,18 . Pada ketermapilan communication skill jugaterdapat peningkatan rerata dari 31,28 menjadi 67,69. Namun karena hasil rerata belum maksimal, diadakan siklus kedua pada keterampilan ini dan menghasilkan rerata 87,38. Pada keterampilan collaborative skill, terjadi peningkatan dari 50,51 menjadi 87,54. Pada keterampilan komputasi (computational skill) terdapat peningkatan rerata yang awal rerata 25,90 menjadi 68,21. Namun karena belum maksimal diadakan siklus kedua dan meningkat menjadi 90,64. Pada keterampilan compassion, terjadi peningkatan dai 36,28 menjadi 87,56.
\end{abstract}

Kata Kunci: Blended Learning, Flipped Learning, 6C for HOTS.

\begin{abstract}
This development research aims to improve students' 6C for HOTS through Blended based Flipped Model Learning. The $6 C s$ referred to critical thinking, creative skills, communication skills, collaborative skills, computation skills and compassion. The percentage of Flipped Learning-based Blended Learning models, $10 \%$ are face-to-face and $90 \%$ are online. The method used is ADDIE method. The ADDIE steps are analysis, design, development, implementation, and evaluation. The results show students' critical thinking skills from an average of 36,67 to 88,28. In creative thinking skills (creative skills) an increase from an average of 60,77 to 87,18. In communication skill skills, there is also an average increase from 31,28 to 67,69. Because the average result was not maximized, held second cycle on this skill and produced an average of 87,38. In collaborative skills, there was an increase from 50,51 to 87,54. In computing skills (computational skills) there is an increase from 25,90 to 68,21. However, because it was not maximal, the second cycle was held and increased to 90,64. In compassion skills, there was an increase from 3628 to 87,56. Based on the results, Blended Learning learning model based on Flipped Learning is very effective in improving students' $6 C$ for HOTS.
\end{abstract}

Keywords: Blended Learning, Flipped Learning, 6C for HOT

Copyright (c) 2021 Suci Perwita Sari, Eko Febri Syahputra Siregar, Baihaqi Siddik Lubis

Corresponding author :

Email : suciperwita@umsu.ac.id

DOI : https://doi.org/10.31004/basicedu.v5i5.1334

ISSN 2580-3735 (Media Cetak)

ISSN 2580-1147 (Media Online) 
3461 Pengembangan Pembelajaran Blended Learning Berbasis Model Flipped Learning untuk Meningkatkan 6C For HOTS Mahasiswa PGSD UMSU - Suci Perwita Sari, Eko Febri Syahputra Siregar, Baihaqi Siddik Lubis

DOI: https://doi.org/10.31004/basicedu.v5i5.1334

\section{PENDAHULUAN}

Pergerakan laju industri yang begitu cepat menuntut seseorang untuk dapat terus berupaya mengikuti perkembangannya agar tidak dieliminasi dengan zaman. Dalam mengupayakan hal ini, pendidikan merupakan arena penting dalam membentuk luaran yang mampu bertahan pada masa. Perguruan tinggi berperan aktif dalam menciptakan sumber daya manusia yang beriman dan bertakwa kepad Tuhan Yang Maha Esa, berakhlak mulia, sehat, berilmu, cakap, kreatif, mandiri dan menjadi warga Negara yang demokratis. Pencapaian tujuan pendidikan ini dilakukan dengan peningkatan kualitas dosen baik dari segi keprofesionalan, pemutakhiran bahan ajar yang digunakan dan penggunaan model belajar yang sesuai dengan Abad 21 . Pembelajaran pada abad 21 pada masa kini bukan hanya menuntut pada kemampuan 4C (collaboration, communication, creative thinking, dan critical thinking) namun juga harus mampu menguasai compassion dan computation. Untuk itu kemampuan yang dituntut bukan lagi 4C namun menjadi 6C (Kemendikbud, 2020).

Program Studi Pendidikan Guru Sekolah Dasar (PGSD) FKIP UMSU berbagai upaya telah dilakukan dalam membentuk lulusan yang unggul sesuai kebutuhan abad 21 yaitu keterampilan 6C. Dosen yang mengajar telah sesuai dengan bidang keilmuan masing-masing, mengadakan penyusunan modul dengan berbagai rujukan terbaru dan mengadakan pelatihan peningkatan keprofesionalan dosen dalam mengajar. Hal ini dapat dibuktikan melalui berbagai luaran pembelajaran mahasiswa yang dapat dijadikan referensi bagi guru di sekolah dasar dalam mengajarkan materi di SD, video digital sebagai sumber media di SD, dan penguasaan model pembelajaran dalam kegiatan microteaching yang dilakukan mahasiswa.

Namun berbagai upaya dan tujuan yang dilakukan oleh Program Studi PGSD terhambat dengan adanya Pandemi Covid 19. Pandemi covid 19 merupakan wabah penyakit yang merusak saluran pernapasan manusia yang berasal dari Wuhan China. Wabah penyakit ini sudah menjangkit hampir seluruh penjuru dunia. Di Indonesia sendiri, pandemi ini diidentifikasi pada awal Maret 2020 hinga sekarang. Berdasarkan hasil data yang diperoleh per tanggal 11 Februari 2021, sebanyak 1,180.000 Juta masyarakat Indonesia telah terjangkit penyakit ini dan 32.126 orang telah meninggal dunia. Berbagai kebijakan telah dilakukan oleh pemerintah dalam meminimalisir penyebaran penyakit ini, salah satunya dengan mengadakan pembatasan kegiatan masyarakat. pembatasan yang dimaksudkan disini adalah masyarakat dilarang untuk keluar rumah jika tidak penting dan melaksanakan segala kegiatan di rumah baik bekerja dan belajar. Dalam pendidikan, kebijakan yang dilakukan adalah melakukan pembelajaran secara daring (dalam jaringan).

Pembelajaran daring dapat dilakukan dengan pemberdayaan penggunaan elearning, pengoperasian zoom meeting dan google classroom dan obrolan via chat wa. Masing-masing penggunaan aplikasi ini memiliki keuntungan dan kerugian dalam penggunaannya. Keuntungan yang didapat adalah jarak semakin dekat, hemat waktu, dan irit biaya. Jarak semakin jauh mengandung arti bahwa mahasiswa dimanapun berada dapat belajar tanpa harus datang ke kampus. Hemat waktu berarti baik mahasiswa maupun dosen tidak membutuhkan waktu yang lama dalam mempersiapkan persiapan belajar mengajar, dan irit biaya bermakna mahasiswa tidak perlu mengeluarkan biaya untuk transportasi, makan siang ataupun akomodasi lainnya terkait pembelajaran.

Disamping berbagai keuntungan tersebut, terdapat juga berbagai kerugian yang ditimbulkan. Dari hasil wawancara singkat dari mahasiswa, respon yang diberikan adalah kurangnya pemahaman terhadap materi pembelajaran, salah dalam melakukan instruksi yang diberikan dosen, kemudahan dalam mengakses jawaban dari internet sehingga jawaban yang diberikan mahasiswa relatif sama dan tidak mengikuti perkuliahan dengan alasan jaringan internet yang buru. Hal demikian ini menyebabkan bahwa perkuliahan melalui daring dianggap tidak penting. Kegiatan perkuliahan dianggap hanya sebagai kegiatan menjawab pertanyaan kemudian mendapatkan nilai. Seyogyanya makna belajar di perguruan tingkat tinggi sendiri adalah bagaimana 
3462 Pengembangan Pembelajaran Blended Learning Berbasis Model Flipped Learning untuk Meningkatkan 6C For HOTS Mahasiswa PGSD UMSU - Suci Perwita Sari, Eko Febri Syahputra Siregar, Baihaqi Siddik Lubis

DOI: https://doi.org/10.31004/basicedu.v5i5.1334

mengubah karakter mahasiswa sesuai dengan sikap capaian lulusan dan berkreasi sehingga menghasilkan karya cipta yang bermakna bagi khalayak.

Pembelajaran daring sering disebut juga Blended Learning merupakan gabungan antara sistem pembelajaran tatap muka dan online learning (Dissriany \& Banggur, 2018). Disatu sisi, ada pembelajaran tatap muka di lingkungan tradisional, disisi lain ada lingkungan pembelajaran terdistribusi yang mulai tumbuh dan berkembang dengan cara-cara eksponensial sebagai teknologi baru yang kemungkinan diperluas untuk distribusi komunikasi dan interaksi. Sejalan dengan pernyataan ini, (Widiara \& Life, 2018) menyatakan bahwa Blended Learning merurpakan sebuah strategi belajar mengajar yang berutjuan untuk mencapiai tujuan pembelajaran dengan cara memadukan pembelajaran berbasis kelas/tatap muka dengan pembelajaran berbasis teknologi dan informasi yang dilakukakn secara daring (online). Dikarenakan adanya kombinasi daring dan luring, maka perlu ditentukan proporsi besaran pelaksanaannya. Beberapa diantaranya ada yang mengadakan $50 \%$ tatap muka, 50\% mandiri, ada yang $70 \%$ tatap muka $30 \%$ mandiri, bahkan $10 \%$ tatap muka $90 \%$ mandiri. Pembelajaran Blended Learning sebenarnya bukan mengenai berapa besar proporsi yang digunakan dalam tatap muka atau mandiri melainkan ada model model khusus dalam pelaksanaannya. Model-model pembelajaran dalam Blended Learning adalah Station Rotation Blended Learning, Lab Rotation Blended Learning, Enriched Virtual, Flex Blended Learning, dan Flipped Learning. Dalam penelitian ini, model yang dikembangkan adalah model flipped learning. Model flipped dikembangkan karena sudah banyak digunakan oleh dosen dalam masa pandemi namun pelaksanaannya masih kurang tepat. Pelaksanaan sesungguhnya adalah mahasiswa telah diberikan materi terlebih dahulu untuk dijadikan bahan apersepsi mahasiswa secara online kemudian bersama dengan bimbingan dosen, mahasiswa menganalisis hipotesis yang telah dibuat baik secara baik maupun berkelompok secara daring.

Penelitian ini didukung oleh penelitian yang dilakukan oleh (Farida et al., 2019) menyimpulkan bahwa model flipped learning dapat membangun kegiatan belajar mengajar secara aktif dan interaktif melalui kegiatan individu maupun berkelompok. Model pembelajaran ini juga mampu membuat peserta didik lebih percaya diri dalam melakukan kegiatan diskusi, tanya jawab, dan memberikan solusi dalam pemecahan berbagai masalah. Senada dengan penelitian yang diadakan oleh (Ario \& Artikel, 2018) menyimpulkan bahwa kelas yang menggunakan model flipped learning memiliki rerata hasil belajar sebesar 74,57 sementara di kelas kontrol memperoleh rerata sebesar 55,83. Ini menunjukkan bahwa kelas yang menerapkan model flipped learning lebih baik daripada kelas yang tidak menggunakan flipped learning. (Ishak, 2019) mengaitkan model flipped learning dengan interaksi sosial mahasiswa. Hasil yang didapat adalah mahasiswa memiliki persepsi positif dalam semua komponen intraksi dalam pembelajaran menggunakan metode flipped learning.

Dari berbagai pernyataan pada latar belakang dan didukung dengan penelitian yang relevan,peneliti tertarik dalam melakukan penelitian pengembangan dengan judul "Pengembangan Blended Learning Berbasis Model Flipped Learning dalam Meningkatkan 6C for Hots Mahasiswa PGSD FKIP T.A 2020/2021". Tujuan diadakannya penelitian ini adalah tersusunnya rancangan perkuliahan daring menggunakan pembelajaran Blended Learning berbasis flipped learning dan implementasinya dalam meningkatkan keterampilan 6C for HOTS mahasiswa.

\section{METODE PENELITIAN}

Penelitian ini dilakukan di Universitas Muhammadiyah Sumatera Utara pada mahasiswa semester II berjumlah 293 orang. Sample dalam penelitian ini diambil melalui random sampling dan diperoleh kelas A pagi berjumlah 29 orang. Desain penelitian ini menggunakan metode Research and Development (R\&D) model ADDIE berupa penelitian lapangan yakni penerapan dari pengembangan model Blended Learning 
3463 Pengembangan Pembelajaran Blended Learning Berbasis Model Flipped Learning untuk Meningkatkan 6C For HOTS Mahasiswa PGSD UMSU - Suci Perwita Sari, Eko Febri Syahputra Siregar, Baihaqi Siddik Lubis

DOI: https://doi.org/10.31004/basicedu.v5i5.1334

berbasis Flipped Learning dalam meningkatkan keterampilan 6C for HOTS Mahasiswa. Alur dalam penelitian ini digambarkan melalui diagram alur dalam skema ADDIE, yaitu :

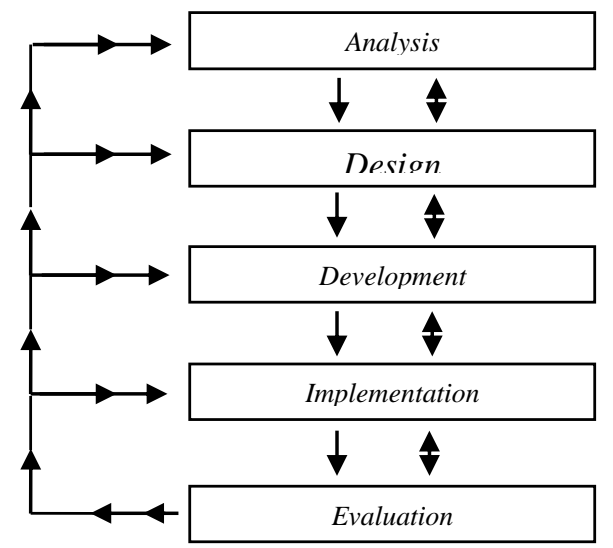

Gambar 1. Model Penelitian dan Pengembangan ADDIE

(Alan Januszewski, 2010)

Pada gambar 1. di atas menjelaskan bahwa jenis penelitian pengembangan model ADDIE memiliki lima tahapan. Gagne Dkk (Arfiliana, 2014) memberikan perluasan dari dasar tahap-tahap ADDIE ke dalam sebuah panduan prosedural yang lebih rinci, yaitu: analysis (analisis), design (desain), development (pengembangan), implementation (pelaksanaan), evaluation (evaluasi).

Pada tahap analisis (analysis) peneliti mencari tahu apa yang harus dibutuhkan mahasiswa dalam belajar pada masa pandemi, sehingga apa yang ingin dicapai oleh mahasiswa dapat terpenuhi. Pada tahap desain (design), peneliti merancang atau membuat rancangan pembelajaran menggunakan pembelajaran Blended Learning berbasis flipped learning. Setelah dirancang model pembelajaran Blended Learning berbasis flipped learning, nantinya akan diperiksa oleh beberapa dosen lainnya yang berkompeten sampai pada tingkat produk tersebut sudah bisa digunakan. Setelah diperiksa oleh para ahli hasilnya menyatakan bahwa rancangan pembelajaran Blended Learning berbasis flipped learning tersebut sudah bisa digunakan dalam pembelajaran, maka pada tahap pengembangan (development) peneliti dapat mengembangkan hasil rancangan pembelajaran Blended Learning berbasis flipped learning sesuai dengan yang dibutuhkan mahasiswa dan dosen. Kemudian pada tahap implementasi (implementation) peneliti terjun ke lapangan untuk mengetahui bagaimana peningkatan kemampuan 6C maupun keefektifan setelah digunakannya rancanagan pembelajaran Blended Learning berbasis flipped learning tersebut. Setelah penggunaan rancangan pembelajaran Blended Learning berbasis flipped learning maka dilakukan tahap evaluasi (evaluation) yang bertujuan untuk melihat pencapaian tujuan peningkatan keterampilan $6 \mathrm{C}$ mahasiswa maupun keefektifan rancangan pembelajaran Blended Learning berbasis flipped learning

Akan tetapi, jika hasil dari langkah yang tidak memuaskan misalnya, rancangan pembelajaran tidak sesuai apa yang diharapkan atau belum bisa digunakan di lapangan, maka langkah pada tahap pengembangan (development) harus diulang atau kembali ke desain (rancangan), artinya rancangan pembelajaran tersebut mash terdapat kesalahan pada saat merancangnya dan tidak perlu mengulang pada tahap analisis. Proses ini mengulangi langkah sampai hasil yang memuaskan.

\section{HASIL DAN PEMBAHASAN}

Hasil penelitian pengembanagan model blended learning berbasis flipped learning untuk meningkatkan keterampilan 6C for HOTS mahasiswa dilakukan dengan tahapan ADDIE dengan hasil : 
3464 Pengembangan Pembelajaran Blended Learning Berbasis Model Flipped Learning untuk Meningkatkan 6C For HOTS Mahasiswa PGSD UMSU - Suci Perwita Sari, Eko Febri Syahputra Siregar, Baihaqi Siddik Lubis

DOI: https://doi.org/10.31004/basicedu.v5i5.1334

Tahap analyse (analisis) diperoleh hasil awal 6C mahasiswa pada aspek critical thinking masih rendah dengan rerata 36,67. Kegiatan pengujian critical thinking dilakukan dengan memberikan masalah kepada mahasiswa terkait pengembangan pembelajaran di Sekolah Dasar dan ditemukan hampir 71,79\% mahasiswa yang menejiplak jawaban dari internet. Pada aspek creative thinking, tingkat kreativitas mahasiswa cukup baik. Pengujian aspek critical thinking dilakukan dengan menugaskan mahasiswa untuk berkreasi membuat media pembelajaran. Persentase mahasiswa membuat dalam bentuk powerpoint sebanyak 30,77\% dalam bentuk 2D (atau dikertas) sebanyak 41,03\% dan 28,20\% dalam bentuk 3D. dengan rerata 60,77. Pada communication skill, mahasiswa diuji dengan menyampaikan pendapatnya secara lisan terkait pengaruh Covid-19 terhadap kreativitas mengajar guru dan siswa, sebanyak 35,90 \% mahasiswa tidak mampu menjawab, 51,29\% menjawab dengan terbata bata, dan 12,82\% cukup lancar memaparkan permasalahan yang diberikan. Pada aspek collaborative skill, pengujian dilakukan dengan menugaskan mahasiswa untuk membuat proyek pengajaran di kelas melalui penyusunan RPP. Sebanyak 71,79\% kelompok tidak sesuai sama sekali dengan kelompoknya, 17,95\% ada yang sesuai dan tidak dan 10,26\% keseluruhan sesuai. Pada aspek computational logic, mahasiswa diinstruksikan untuk membuat undangan akun zoom dan merancang google, namun hanya $2,56 \%$ yang mampu untuk menyelesaikannya. Selanjutnya pada keterampilan akhir, compassion (sikap perhatian), diberika angket terkait dengan compassion. Hasil yang diperoleh adalah hampir keseluruhan mahasiswa kurang peduli terhadap lingkungan dan perubahan yang terjadi disekitarnya.

Tahap analisis juga dilakukan dengan menganalisis kegiatan perkuliahan daring yang selama ini terjadi. Perkuliahan daring yang selama ini terjadi adalah dosen dan mahasiswa $100 \%$ hanya melakukan tatap muka melalui zoom maksimal 40 menit. Adapun tugas yang diberikan lebih kepada bentuk pertanyaan dan dikirim melalui elearning. Absensi perkuliahan juga dilakukan melalui elearning. Pada waktu yang ditentukan, tugas dikumpul dan masuk ke pertemuan berikutnya dengan metode ceramah.

Berdasarkan analisis ini maka dilanjutkan ke tahap design (desain). Hakikatnya flipped learning merupakan kegiatan pembelajaran yang dilakukan dengan tatatp muka dan daring. Adapun proporsi yang disarankan adalah 50\% tatap muka, 50\% mandiri, ada yang 70\% tatap muka 30\% mandiri, bahkan 10\% tatap muka 90\% mandiri (Junaidi, 2020). Adapun tahapam utamanya dilakukan dengan kegiatan pengenalan materi yang dilakukan secara daring dengan dosen memberikan bahan bacaan kepada mahasiswa. Selanjutnya untuk pemaparan materi dan praktek konsep utama materi dilakukan dengan tatap muka dan tugas evaluasi dialkukan secara daring untuk memberikan kesempatan kepada mahasiswa memperluas pemahamannya diluar kelas. Namun dikarenakan masih mewabahnya covid 19, maka peneliti sepakat untuk memilih proporsi $10 \%$ tatap muka dan $90 \%$ daring dalam pelaksanaan penelitian ini.

Pada tahap development (pengembangan), model blended learning berbasis flipped dilakukan dengan memberikan masalah kepada mahasiswa untuk dipecahkan bersama melalui zoom meeting yang mereka buat sendiri dengan teman sekelompoknya 30 menit sebelumnya perkuliahan daring dimulai. Kegiatan pembelajaran ini melatih kemampuan mereka dalam berkolaborasi (collaborative skill) dan berpikir kritis (critical thinking) dalam memberikan sumbangsih ide dengan teman sekelompoknya. Selanjutnya diadakan perkuliahan secara daring seluruh kelas utama dengan dosen. Pada kegiatan ini, dosen menguji kemampuan computational mahasiswa dengan menunjuk siapa yang menjadi host pada pertemuan itu melalui whatsapp. Selanjutnya perkuliahan dikelas utama berlangsung, dosen meminta pendapat mahasiswa terkait hasil pembahasan yang mereka lakukan sebelumnya dan dilakukan diskusi multi arah untuk meningkatkan kemampuan berkomunikasi mahasiswa (communication skill). Untuk akhir kegiatan, dosen memberikan tugas kepada mahasiswa secara individu namun dapat dikerjakan secara berkelompok. Adapun tugas yang diberikan adalah mahasiswa diinstruksikan untuk mengembangang adiministrasi pembelajaran seperti media pembelajaran, bahan ajar, dan RPP. Kegiatan ini bertujuan dalam meningkatkan kreativitas mahasiswa (creativity skill) dalam mengembangkan pengetahuan dan pengalaman dalam pembelajaran di Sekolah Dasar. 
3465 Pengembangan Pembelajaran Blended Learning Berbasis Model Flipped Learning untuk Meningkatkan 6C For HOTS Mahasiswa PGSD UMSU - Suci Perwita Sari, Eko Febri Syahputra Siregar, Baihaqi Siddik Lubis

DOI: https://doi.org/10.31004/basicedu.v5i5.1334

Selanjutnya, dikarenakan masa new normal, dosen memberikan kesempatan kepada perwakilan kelompok untuk bertemu secara tatap muka atas kesulitan yang dihadapi selama proses pengerjaan tugas. Melalui kegiatan ini, mahassiwa yang mengalami kesulitan dapat melapor kepada perwakilan kelompoknya untuk dibahas secara tatap muka dengan dosennya. Setelah itu, pertemuan kelompok membahas ulang kembali hasil pertemuan secara tatap muka kepada teman sekelompoknya melalui daring. Kegiatan ini diharapkan dapat meningkatkan compassion (Rasa kasih sayang) mahasiswa dengan teman sejawatnya

Pada tahap implementation (implementasi), dosen melaksanakan kegiatan-kegiatan yang telah direncanakan pada tahap desain. Tahap implementasi dilakukan dengan mempersiapkan segala instrument penilaian dan pemberian tindakan yaitu model blended learning berbasis flipped learning dalam meningkatkan 6C for HOTS mahasiswa.

Pada tahap evaluation (evaluasi), dilakukan analisis terhadap hasil 6C mahasiswa melalui model pembelajaran blended learning berbasis flipped learning. Adapun hasil yag diperoleh dalam tahap evaluasi pada siklus I adalah :

Tabel 1. Hasil Pretes dan Postes Kemampuan Critical Thinking

\begin{tabular}{|c|c|c|c|}
\hline No & Nilai & Frekuensi & Persentase \\
\hline 1 & 11 & 6 & 15.38 \\
\hline 2 & 22 & 7 & 17.95 \\
\hline 3 & 33 & 7 & 17.95 \\
\hline 4 & 44 & 8 & 20.51 \\
\hline 5 & 55 & 9 & 23.08 \\
\hline 6 & 66 & 2 & 5.13 \\
\hline \multicolumn{2}{|c|}{ Jumlah } & 39 & 100 \\
\hline \multicolumn{2}{|c|}{ Mean } & 36.67 & \\
\hline
\end{tabular}

\begin{tabular}{cccc}
\hline No & Nilai & Frekuensi & Persentase \\
\hline 2 & 77 & 8 & 20.51 \\
\hline 3 & 88 & 22 & 56.41 \\
\hline 4 & 99 & 9 & 23.08 \\
\hline Jumlah & \multicolumn{3}{c}{} \\
\hline \multicolumn{2}{c}{ Mean } & $\mathbf{8 8 . 2 8}$ \\
\hline
\end{tabular}

Berdasarkan tabel 1 diatas diperoleh data bahwa terdapat peningkatan critical thinking mahasiswa dari rerata sebesar 36,67 menjadi 88,28. Hal ini menunjukkan terdapat peningkatan sebesar 51,61. Hasil rerata ayng dapat jika dikonversikan dalam huruf, maka berkategori A. untuk itu pengembangan model blended learning berbasis flipped learning berhasil dalam meningkatkan kemampuan critical thinking mahasiswa. Keterampilan thinking skill merupakan keterampilan yang harus diperhatikan dan perlu ditingkatkan sebagai bekal mahasiswa dalam menyelesaikan masalah yang terjadi. Penelitian yang dilakukan oleh (Suparni, 2020) menyimpulkan bahwa dengan adanya critical thinking skill, maka mahasiswa mampu melatih dan mengembangkan infromasi yang diperoleh serrta dapat membedakan informasi dan pendapatnya. Mahasiswa juga mempunya rasa ingin tahun yang tinggi dan dapat mengembangkan sudut pandangnya.

Untuk hasil evaluasi creativity mahasiswa dengan menggunakan pengembangan model blended learning berbasis flipped learning, dapat dilihat pada tabel dibawah ini.

Tabel 2. Hasil Pretes dan Postes Kemampuan Creative Skill

\begin{tabular}{cccc}
\hline No & Nilai & Frekuensi & Persentase \\
\hline 1 & 40 & 2 & 5.13 \\
\hline 2 & 50 & 10 & 25.64 \\
\hline 3 & 60 & 16 & 41.03 \\
\hline 4 & 70 & 5 & 12.82 \\
\hline 5 & 80 & 6 & 15.38 \\
\hline
\end{tabular}


3466 Pengembangan Pembelajaran Blended Learning Berbasis Model Flipped Learning untuk Meningkatkan 6C For HOTS Mahasiswa PGSD UMSU - Suci Perwita Sari, Eko Febri Syahputra Siregar, Baihaqi Siddik Lubis

DOI: https://doi.org/10.31004/basicedu.v5i5.1334

\begin{tabular}{ccc}
\hline Jumlah & 39 & 100 \\
\hline Mean & 60.77 & \\
\hline
\end{tabular}

\begin{tabular}{cccc}
\hline No & Nilai & Frekuensi & Persentase \\
\hline 1 & 70 & 4 & 10.26 \\
\hline 2 & 80 & 12 & 30.77 \\
\hline 3 & 90 & 14 & 35.90 \\
\hline 4 & 100 & 9 & 23.08 \\
\hline Jumlah & $\mathbf{3 9}$ & $\mathbf{1 0 0}$ \\
\hline Mean & \multicolumn{3}{c}{} \\
\hline
\end{tabular}

Berdasarkan tabel 2 diatas diperoleh data bahwa terdapat peningkatan creative skill mahasiswa dari rerata sebesar 60,77 menjadi 87,18 . Hal ini menunjukkan terdapat peningkatan sebesar 26,41 . Hasil rerata yang didapat jika dikonversikan dalam huruf, maka berkategori A. untuk itu pengembangan model blended learning berbasis flipped learning berhasil dalam meningkatkan kemampuan creative skill mahasiswa. Creative skill merupakan salah satu keterampilan yang sangat harus dimiliki oleh mahasiswa, penelitian yang dilakukan oleh (Mardhiyana et al., 2015) menyimpulkan bahwa ketika kemampuan berpikir kreatif seseorang berkembang, maka akan melahirkan gagasan/ide, menemukan gungan yang saling berkaitan, membuat dan melakukan imajinasii, seta mempunyai banyak perspektif terhadap suatu hal sehingga ia mampu menyelesaikan berbagai masalah dalam belajar.

Untuk hasil evaluasi communication skill mahasiswa dengan menggunakan pengembangan model blended learning berbasis flipped learning, dapat dilihat pada tabel dibawah ini.

Tabel 3. Hasil Pretes dan Postes Kemampuan Communication Skill

\begin{tabular}{|c|c|c|c|c|c|c|c|}
\hline No & Nilai & Frekuensi & Persentase & No & Nilai & Frekuensi & Persentase \\
\hline 1 & 20 & 14 & 35.90 & 1 & 50 & 5 & 12.82 \\
\hline 2 & 30 & 11 & 28.21 & 2 & 60 & 12 & 30.77 \\
\hline 3 & 40 & 9 & 23.08 & 3 & 70 & 10 & 25.64 \\
\hline 4 & 50 & 5 & 12.82 & 4 & 80 & 11 & 28.21 \\
\hline \multicolumn{2}{|c|}{ Jumlah } & 39 & 100 & 5 & 90 & 1 & 2.56 \\
\hline \multirow{2}{*}{\multicolumn{2}{|c|}{ Mean }} & 31.28 & & \multicolumn{2}{|c|}{ Jumlah } & 39 & 100 \\
\hline & & & & \multicolumn{2}{|c|}{ Mean } & 67.69 & \\
\hline
\end{tabular}

Berdasarkan tabel 3 diatas diperoleh data bahwa terdapat peningkatan comuunication skill mahasiswa dari rerata sebesar 31,28 menjadi 67,69. Hal ini menunjukkan terdapat peningkatan sebesar 36,41. Hasil rerata yang didapat jika dikonversikan dalam huruf, maka berkategori B-. berdasarkan hasil ini, pengembangan model blended learning berbasis flipped learning mampu meningkatkan kemampuan communication skill mahasiswa namun belum mencapai kategori penilaian maksimal. Untuk itu diperlukan adanya pengembangan model blended learning berbasis flipped learning dalam meningkatkan communication skill mahasiswa. Berdasarkan penelitian yang dilakukan oleh (Marfuah, 2017) dikemukakan bahwa keterampilan komunikasi dalam pembelajaran merupakan keterampulan yang harus dimiliki dan dikuasai oleh seorang peserta didik karena keterampilan ini bertujuan menggali pengetahuan sebanyak-banyaknya serta untuk menyampaikan informasi kepada masyarakat baik secara lisan maupun tulisan. Komunikasi dalam pembelajaran akan menciptakan pembelajaran menjadi efektif karena terbangun komunikasi antara guru dan peserta didik, ataupun sesama peserta didik sehingga tujuan pembelajaran dapat tercapai. 
3467 Pengembangan Pembelajaran Blended Learning Berbasis Model Flipped Learning untuk Meningkatkan 6C For HOTS Mahasiswa PGSD UMSU - Suci Perwita Sari, Eko Febri Syahputra Siregar, Baihaqi Siddik Lubis

DOI: https://doi.org/10.31004/basicedu.v5i5.1334

Untuk hasil evaluasi collaborative skill mahasiswa dengan menggunakan pengembangan model blended learning berbasis flipped learning, dapat dilihat pada tabel dibawah ini.

Tabel 4. Hasil Pretes dan Postes Kemampuan Collaborative Skill

\begin{tabular}{|c|c|c|c|c|c|c|c|}
\hline No & Nilai & Frekuensi & Persentase & No & Nilai & Frekuensi & Persentase \\
\hline 1 & 40 & 13 & 33.33 & 1 & 75 & 6 & 15.38 \\
\hline 2 & 50 & 15 & 38.46 & 2 & 80 & 2 & 5.13 \\
\hline 3 & 60 & 7 & 17.95 & 3 & 85 & 7 & 17.95 \\
\hline 4 & 70 & 4 & 10.26 & 4 & 90 & 13 & 33.33 \\
\hline \multicolumn{2}{|c|}{ Jumlah } & 39 & 100 & 5 & 93 & 3 & 7.69 \\
\hline \multirow{3}{*}{\multicolumn{2}{|c|}{ Mean }} & 50.51 & & 6 & 95 & 8 & 20.51 \\
\hline & & & & \multicolumn{2}{|c|}{ Jumlah } & 39 & 100 \\
\hline & & & & \multicolumn{2}{|c|}{ Mean } & 87.54 & \\
\hline
\end{tabular}

Berdasarkan tabel 4 diatas diperoleh data bahwa terdapat peningkatan collaborative skill mahasiswa dari rerata sebesar 50,51 menjadi 87,54. Hal ini menunjukkan terdapat peningkatan sebesar 37,2. Hasil rerata yang didapat jika dikonversikan dalam huruf, maka berkategori A. Hasil ini menunjukkan bahwa pengembangan model blended learning berbasis flipped learning mampu meningkatkan kemampuan collaborative skill mahasiswa. Collaborative skill merupakan keterampilan yang harus dimiliki mahasiswa. Indicator dari penelitian ini menurut (Kristianti et al., 2019) adalah saling berpendapat, mempercayai anggota kelompok, membangun rasa solidaritas, mengutamakan keterampilan mendengarkan, bertukar informasi, bertanggung jawab dan saling berkoordinas. Ketika semua indikator ini dimiliki mahasiswa, maka pemerolehan ilmu buka lagi kompetisi melainkan menjadi kordinasi yang salaing bersinergi dalam mencapai tujuan pembelajaran.

Untuk hasil evaluasi computational mahasiswa dengan menggunakan pengembangan model blended learning berbasis flipped learning, dapat dilihat pada tabel dibawah ini.

Tabel 5. Hasil Pretes dan Postes Kemampuan Computational

\begin{tabular}{cccc}
\hline No & Nilai & Frekuensi & Persentase \\
\hline 1 & 0 & 3 & 7.69 \\
2 & 20 & 18 & 46.15 \\
\hline 3 & 30 & 8 & 20.51 \\
\hline 4 & 40 & 9 & 23.08 \\
\hline 5 & 50 & 1 & 2.56 \\
\hline \multicolumn{2}{c}{ Jumlah } & $\mathbf{3 9}$ & $\mathbf{1 0 0}$ \\
\hline \multicolumn{2}{c}{ Mean } & $\mathbf{2 5 . 9 0}$ \\
\hline
\end{tabular}

Berdasarkan tabel 5 diatas diperoleh data bahwa terdapat peningkatan computational mahasiswa dari rerata sebesar 25,90 menjadi 68,21. Hal ini menunjukkan terdapat peningkatan sebesar 42,31. Hasil rerata yang didapat jika dikonversikan dalam huruf, maka berkategori B. Hasil ini menunjukkan bahwa pengembangan model blended learning berbasis flipped learning mampu meningkatkan kemampuan computational mahasiswa namun hasil konversi huruf belum menunjukkan hasil yang maksimal. Untuk itu perlu diadakan peningkatan terhadap pengembangan model blended learning berbasis flipped learning untuk 
3468 Pengembangan Pembelajaran Blended Learning Berbasis Model Flipped Learning untuk Meningkatkan 6C For HOTS Mahasiswa PGSD UMSU - Suci Perwita Sari, Eko Febri Syahputra Siregar, Baihaqi Siddik Lubis

DOI: https://doi.org/10.31004/basicedu.v5i5.1334

meningkatkan kemampuan computational mahasiswa. Peningkatan computation menjadi penting sebab berdasarkan hasil studi literatur yang dilakukan oleh (Anistyasari et al., 2019) berpendapat bahwa kemampuan komputasi tidak lagi berfokus pada matematis dan pemograman saja, namun kini sudah merambah dalam segala mode pengajaran linyas domain untuk memungkinkan siswa mengelola dan menganalisis materi dengan komputasi. Dalam pengembangan nantinya, peningkatan keterampilan computation dilakukan melalui indicator indicator komputasi meliputi dekomposisi masalah, berpikir Algoritma, pengenalan pola, dan abstraksi. Indicator ini dikemukakan oleh Cahdriyana \& Ricahrdo (Augie \& Priatna, 2021).

Untuk hasil evaluasi compassion mahasiswa dengan menggunakan pengembangan model blended learning berbasis flipped learning, dapat dilihat pada tabel dibawah ini.

Tabel 6. Hasil Pretes dan Postes Kemampuan Compassion Mahasiswa

\begin{tabular}{|c|c|c|c|c|c|c|c|}
\hline No & Nilai & Frekuensi & Persentase & No & Nilai & Frekuensi & Persentase \\
\hline 1 & 15 & 2 & 5.13 & 1 & 70 & 1 & 2.56 \\
\hline 2 & 20 & 6 & 15.38 & 2 & 75 & 3 & 7.69 \\
\hline 3 & 25 & 5 & 12.82 & 3 & 80 & 5 & 12.82 \\
\hline 4 & 30 & 2 & 5.13 & 4 & 85 & 6 & 15.38 \\
\hline 5 & 35 & 5 & 12.82 & 5 & 90 & 14 & 35.90 \\
\hline 6 & 40 & 8 & 20.51 & 6 & 95 & 10 & 25.64 \\
\hline 7 & 45 & 1 & 2.56 & \multicolumn{2}{|c|}{ Jumlah } & 39 & 100 \\
\hline 8 & 50 & 4 & 10.26 & \multicolumn{2}{|c|}{ Mean } & 87.56 & \\
\hline 9 & 55 & 4 & 10.26 & & & & \\
\hline 10 & 60 & 2 & 5.13 & & & & \\
\hline \multicolumn{2}{|c|}{ Jumlah } & 39 & 100 & & & & \\
\hline \multicolumn{2}{|c|}{ Mean } & 36.28 & & & & & \\
\hline
\end{tabular}

Berdasarkan tabel 6 diatas diperoleh data bahwa terdapat peningkatan compassion mahasiswa dari rerata sebesar 36,28 menjadi 87,56. Hal ini menunjukkan terdapat peningkatan sebesar 51,28. Hasil rerata yang didapat jika dikonversikan dalam huruf, maka berkategori A. Hasil ini menunjukkan bahwa pengembangan model blended learning berbasis flipped learning mampu meningkatkan kemampuan compassion mahasiswa. Penelitian yang dilakukan oleh (Hasmarlin \& Hirmaningsih, 2019) menyimpulkan bahwa semakin tinggi compassion yang dimiliki seseorang maka semakin tinggi pula pengelolaan emosi yang dimilikinya. Dengan demikian semakin diterima seseorang dalam masyarakat.

Dari hasil tahap evaluasi diatas, terdapat 2 kemampuan yang perlu diadakan peningkatan (development) yaitu keterampilan communication skill dan computational skill mahasiswa. Peningkatan ini dilakukan karena hasil peningkatan belum pada kategori angka yang maksimal.

Pada tahap development (pengembangan), kegiatan yang dilakukan adalah upaya memperbaiki proses pembelajaran menggunakan model blended learning berbasis flipped learning dalam peningkatan communication skill dan computational mahasiswa. Adapun pengembangan yang dilakukan adalah dalam peningkatan communication skill, mahasiswa diberikan masalah baru mengenai masalah yang terjadi dalam pembelajaran. Selanjutnya mahasiswa diinstruksikan untuk mencari beberapa referensi jurnal terkait peningkatan pembelajaran di kelas. Setelah jurnal didapat, maka mahasiswa diinstruksikan untuk menuliskan pendapatnya dalam sebuah kertas sebelum diadakan pertemuan secara daring dengan dosen dan mahasiswa lainnya. Pada saat pertemuan daring, dosen menginstruksikan untuk menyampaikan apa yang mereka telah tulis kedalam bentuk lisan. (Gumono, 2018) menjelaskan bahwa melalui kebiasaan membaca, mahasiswa dapat memperoleh pengalaman perbendaharaan kata, sturktur kalimat, dan pola penalaran yang akan 
3469 Pengembangan Pembelajaran Blended Learning Berbasis Model Flipped Learning untuk Meningkatkan 6C For HOTS Mahasiswa PGSD UMSU - Suci Perwita Sari, Eko Febri Syahputra Siregar, Baihaqi Siddik Lubis

DOI: https://doi.org/10.31004/basicedu.v5i5.1334

membantu pengembangan keerampilan analisis. Keterampilan analisis ini nantinya akan memotivasi kemampuan berpikir tingkat tinggi mahasiswa sehingga ia mampu menganalogikan suatu hal melalui katakata.

Peningkatan computational skill dilakukan dengan memberikan soal evaluasi mahasiswa yang biasanya dari google form dan elearning, menjadi menggunakan fasilitas Quizziz. (Pusparani \& Pd, 2020) menyimpulkan bahwa terdapat interaksi antara peserta didik ketika mengerjakan evaluasi pembelajaran sehingga mereka termotivasi dalam belaar dan merasa senang. Dengan motivasi mahasiswa yang tinggi, maka mahasiswa akan berusaha untuk dapat bergabung kedalam quizziz. Hal seperti ini akan mampu meningkatkan keterampilan computational (berkomputasi) mahasiswa.

Setelah diadakan kegiatan development dan design proses peningkatan communication skill dan computational, maka diadakan implementasi kegiatan. Hasil yang diperoleh dalam proses implementasi siklus II akan dievaluasi kembali.

Untuk hasil evaluasi communication skill mahasiswa pada siklus dengan menggunakan pengembangan model blended learning berbasis flipped learning, dapat dilihat pada tabel dibawah ini.

Tabel 7. Hasil Postes I dan Postes II Kemampuan Communication Skill

\begin{tabular}{cccc}
\hline No & Nilai & Frekuensi & Persentase \\
\hline 1 & 50 & 5 & 12.82 \\
\hline 2 & 60 & 12 & 30.77 \\
\hline 3 & 70 & 10 & 25.64 \\
\hline 4 & 80 & 11 & 28.21 \\
\hline 5 & 90 & 1 & 2.56 \\
\hline \multicolumn{2}{c}{ Jumlah } & $\mathbf{3 9}$ & $\mathbf{1 0 0}$ \\
\hline \multicolumn{2}{c}{ Mean } & $\mathbf{6 7 . 6 9}$ \\
\hline
\end{tabular}

\begin{tabular}{cccc}
\hline No & Nilai & Frekuensi & Persentase \\
\hline 1 & 80 & 11 & 28.21 \\
\hline 2 & 90 & 27 & 69.23 \\
\hline 3 & 98 & 1 & 2.56 \\
\hline \multicolumn{2}{c}{ Jumlah } & $\mathbf{3 9}$ & $\mathbf{1 0 0}$ \\
\hline \multicolumn{2}{c}{ Mean } & $\mathbf{8 7 . 3 8}$ \\
\hline
\end{tabular}

Berdasarkan tabel 7 diatas diperoleh data bahwa terdapat peningkatan comuunication skill mahasiswa dari rerata sebesar 67,69 menjadi 87,38. Hal ini menunjukkan terdapat peningkatan sebesar 19,69. Hasil rerata yang didapat jika dikonversikan dalam huruf, maka berkategori A. Berdasarkan hasil ini, pengembangan model blended learning berbasis flipped learning mampu meningkatkan kemampuan communication skill mahasiswa.

Untuk hasil evaluasi computational skill mahasiswa pada siklus dengan menggunakan pengembangan model blended learning berbasis flipped learning, dapat dilihat pada tabel dibawah ini.

Tabel 8. Hasil Postes I dan Postes II Kemampuan Computational Skill

\begin{tabular}{|c|c|c|c|c|c|c|c|}
\hline No & Nilai & Frekuensi & Persentase & No & Nilai & Frekuensi & Persentase \\
\hline 1 & 40 & 1 & 2.56 & 1 & 80 & 3 & 7.69 \\
\hline 2 & 50 & 3 & 7.69 & 2 & 85 & 3 & 7.69 \\
\hline 3 & 60 & 12 & 30.77 & 3 & 90 & 19 & 48.72 \\
\hline 4 & 70 & 11 & 28.21 & 4 & 95 & 14 & 35.90 \\
\hline 5 & 80 & 10 & 25.64 & \multicolumn{2}{|c|}{ Jumlah } & 39 & 100 \\
\hline 6 & 90 & 2 & 5.13 & \multicolumn{2}{|c|}{ Mean } & 90.64 & \\
\hline \multicolumn{2}{|c|}{ Jumlah } & 39 & 100 & & & & \\
\hline \multicolumn{2}{|c|}{ Mean } & \multicolumn{2}{|l|}{68.21} & & & & \\
\hline
\end{tabular}


3470 Pengembangan Pembelajaran Blended Learning Berbasis Model Flipped Learning untuk Meningkatkan 6C For HOTS Mahasiswa PGSD UMSU - Suci Perwita Sari, Eko Febri Syahputra Siregar, Baihaqi Siddik Lubis

DOI: https://doi.org/10.31004/basicedu.v5i5.1334

Berdasarkan tabel 8 diatas diperoleh data bahwa terdapat peningkatan comuunication skill mahasiswa dari rerata sebesar 68,21 menjadi 90,64. Hal ini menunjukkan terdapat peningkatan sebesar 22,43. Hasil rerata yang didapat jika dikonversikan dalam huruf, maka berkategori A. Berdasarkan hasil ini, pengembangan model blended learning berbasis flipped learning mampu meningkatkan kemampuan computational skill mahasiswa.

Hasil penelitian terdahulu yang mendukung penelitian ini adalah penelitian yang dilakukan oleh (Damayanti, 2016) menyatakan bahwa model pembelajaran Flipped Learning efektif dalam meningkatkan sikap kreatif, tanggungjawab, dan keterampilan belajar siswa. hasil ini didapat dari hasil analisis statistik yang menunjukkan bahwa uji analisis non parametric Mann-Whitney menunjukkan tingkat signifikasi masingmasing sebesar 0,003; 0,008; 0,009 lebih kecil dari 0,05. Studi lain yang mendukung penelitian ini adalah hasil studi kasus yang diadakan oleh Farida (2019) yang menyimpulkan bahwa model pembelajaran inovatif flipped learning berpotensi untuk diterapkan dalam kegiatan belajar mengajar di perguruan tinggi, bertujuan dalam membangun budaya belajar mandiri dan berpikir kritis mahasiswa. Komponen keterampilan 6C khususnya collaboration (kolaborasi), critical thinking (berpikir kritis) dan creative thinking (berpikir kreatif) merupakan beberapa indikator dalam taksonomi Bloom untuk HOTS (High Order Thinking Skill). Hasil penelitian (Anugrah et al., 2021) mengungkapkan bahwa learning during the Covid 19 Pandemic using flipped classroom in the E-Learning Design courses has met ten online learning standars by AECT dan provides satisfaction for students and lectures. In addition, the use of technology does not need to be grandiose because the digital platform often used to daily basis to utilize the flipped classroom. Ini bermakna bahwa model pembelajaran berbasis flipped learning baik digunakan dalam pembelajaran daring selama masa pandemic Covid 19 sebab model ini mampu menaungi seluruh kebutuhan dasar dalam pembelajaran. Berdasarkan hasil perhitungan dan penelitian terdahulu, maka pengembangan model Blended Learning Berbasis efektif dalam meningkatkan keterampilan 6C mahasiswa.

\section{KESIMPULAN}

Pengembangan model Blended Learning berbasis Flipped Learning dalam meningkatkan keterampilan 6C for HOTS mahasiswa dikembangkan dengan langkah langkah analisis (analyze), perancangan (design), pengembangan (development), implementasi (implementation), dan evaluasi (evaluation). Berdasarkan hasil perhitungan dan pembahasan dapat disimpulkan bahwa model pembelajaran Blended Learning berbasis Flipped Learning sangat efektif dalam meningkatkan 6C for HOTS mahasiswa. Hal ini dapat dilihat dari hasil pehitungan keterampilan berpikir kritis (critical thinking) mahasiswa dari rerata 36,67 menjadi 88,28. Pada keterampilan berpikir kreatif (creative skill) terjadi peningkatan dari rerata 60,77 menjadi 87,18. Pada ketermapilan communication skill jugaterdapat peningkatan rerata dari 31,28 menjadi 67,69. Namun karena hasil rerata belum maksimal, diadakan siklus kedua pada keterampilan ini dan menghasilkan rerata 87,38. Pada keterampilan collaborative skill, terjadi peningkatan dari 50,51 menjadi 87,54. Pada keterampilan komputasi (computational skill) terdapat peningkatan rerata yang awal rerata 25,90 menjadi 68,21. Namun karena belum maksimal diadakan siklus kedua dan meningkat menjadi 90,64. Pada keterampilan compassion, terjadi peningkatan dai 36,28 menjadi 87,56.

\section{Daftar Pustaka}

Alan Januszewski, M. M. (2010). Educational Technology (I). Routledge Taylor And Francis Group.

Anistyasari, Y., Ekohariadi, \& Munoto. (2019). Strategi Pembelajaran Untuk Meningkatkan Keterampilan Pemrograman Dan Berpikir Komputasi: Sebuah Studi Literatur. Journal Of Vocational And Technical 
3471 Pengembangan Pembelajaran Blended Learning Berbasis Model Flipped Learning untuk Meningkatkan 6C For HOTS Mahasiswa PGSD UMSU - Suci Perwita Sari, Eko Febri Syahputra Siregar, Baihaqi Siddik Lubis

DOI: https://doi.org/10.31004/basicedu.v5i5.1334

Education, 02, 37-44.

Anugrah, A., Ibrahim, N., \& Sukardjo, M. (2021). How Flipped Classroom Helps The Learning In The Times Of Covid-19 Era? Jtp - Jurnal Teknologi Pendidikan, 22(3), 151-158. Https://Doi.Org/10.21009/Jtp.V22i3.17555

Arfiliana. (2014). Pengembangan Bahan Ajar Bentuk Komik Dan Lembar Kerja Siswa Dengan Pendekatan Matematika Realistik Untuk Meningkatkan Hasil Belajar Siswa Kelas Iii Sd Negeri 060843 Kecamatan Medan Barat [Universitas Negeri Medan]. Https://Hsgm.Saglik.Gov.Tr/Depo/Birimler/SaglikliBeslenme-Hareketli-Hayat-Db/Yayinlar/Kitaplar/Diger-Kitaplar/Tbsa-Beslenme-Yayini.Pdf

Ario, M., \& Artikel, I. (2018). Pengaruh Pembelajaran Flipped Learning Terhadap Hasil Belajar Kalkulus Integral Mahasiswa Pendidikan Matematika. Jurnal Ilmiah Pendidikan Matematika, 1(2).

Augie, K. T., \& Priatna, N. (2021). Jurnal Didactical Mathematics Penggunaan Podcast Untuk Mengembangkan Keterampilan Berpikir Komputasi Siswa Selama Gangguan Pandemi. 3(April), 41-47.

Damayanti, H. N. (2016). Efektitvitas Flipped Classroom Terhadap Sikap Dan Keterampilan Belajar Matematika Di Smk. 11(2), 1-7.

Dissriany, M., \& Banggur, V. (2018). Pengembangan Pembelajaran Berbasis Blended Learning Pada Mata Pelajaran Etimologi Multimedia. Jurnal Teknologi Pendidikan, 20(2), 153-165.

Farida, R., Alba, A., Kurniawan, R., \& Zainuddin, Z. (2019). Pengembangan Model Pembelajaran Flipped Classroom Dengan Taksonomi Bloom Pada Mata Kuliah Sistem Politik. Jurnal Teknologi Pendidikan, 07(02), 104-122.

Gumono, A. T. (2018). Menulis Analisis Wacana. Jurnal Pendidikan Dompet Dhuafa, 8(1), 13-20.

Hasmarlin, H., \& Hirmaningsih, H. (2019). Self-Compassion Dan Regulasi Emosi Pada Remaja. Jurnal Psikologi, 15(2), 148. Https://Doi.Org/10.24014/Jp.V15i2.7740

Ishak, T. (2019). Implementasi Model Pembelajaran Flipped Learning Classroom Guna Meningkatkan Interaksi Belajar Mahasiswa Pada Mata Kuliah Manajemen Informasi Dan E-Administrasi. Edcomtech, 4(2), 109-119.

Junaidi, A. (2020). Panduan Penyusunan Kurikulum Pendidikan Tinggi (S. S. Kusumawardani (Ed.); Iv). Direktorat Jenderal Pendidikan Tinggi Kementerian Pendidikan Dan Kebudayaan.

Kemendikbud. (2020). Panduan Penyusunan Kurikulum Pendidikan Tinggi (K. Direktorat Jenderal Pendidikan Tinggi (Ed.)).

Kristianti, Y., Mawardi, M., \& Astuti, S. (2019). Peningkatan Collaborative Skill Dan Hasil Belajar Matematika Siswa Kelas 4 Melalui Model Teams Games Tournament. Pythagoras: Jurnal Program Studi Pendidikan Matematika, 8(1), 1-10. Https://Doi.Org/10.33373/Pythagoras.V8i1.1759

Mardhiyana, D., Octaningrum, E., \& Sejati, W. (2015). Mengembangkan Kemampuan Berpikir Kreatif Dan Rasa Ingin Tahu Melalui Model Pembelajaran Berbasis Masalah.

Marfuah. (2017). Meningkatkan Keterampilan Komunikasi Peserta Didik Melalui Model Pembelajaran Kooperatif Tipe Jigsaw. Jurnal Pendidikan Ilmu Sosial, 26(2), 148-160.

Pusparani, H., \& Pd, M. (2020). Media Quizizz Sebagai Aplikasi Evaluasi Pembelajaran Kelas Vi Di Sdn Gunturkota Cirebon. Jurnal Pendidikan Dasar: Jurnal Tunas Nusantara, 2(2), 269-279.

Suparni, S. (2020). Upaya Meningkatkan Kemampuan Berpikir Kritis Mahasiswa Menggunakan Bahan Ajar Berbasis Integrasi Interkoneksi. Jurnal Derivat: Jurnal Matematika Dan Pendidikan Matematika, 3(2), 40-58. Https://Doi.Org/10.31316/J.Derivat.V3i2.716

Widiara, I. K., \& Life, L. (2018). Blended Learning Sebagai Alternatif Pembelajaran Di Era Digital. Purwadita, 2(2). 